\title{
Low maternal leptin levels in preeclamptic women with fetal growth restriction"
}

\author{
Herman Sumawan ${ }^{1,2 \#}$, Benny Hasan Purwara ${ }^{1}$, Sofie Rifayani Krisnadi ${ }^{1}$ \\ ${ }^{1}$ Department of Obstetrics and Gynecology, Faculty of Medicine, Padjadjaran University/Hasan Sadikin Hospital, Bandung, Indo- \\ nesia \\ ${ }^{2}$ Department of Obstetrics and Gynecology, Faculty of Medicine and Health Sciences, Soedirman University, Purwokerto, Indonesia \\ Email: ${ }^{\#}$ h_sumawan@yahoo.com
}

Received 4 July 2013; revised 2 August 2013; accepted 9 August 2013

Copyright (C) 2013 Herman Sumawan et al. This is an open access article distributed under the Creative Commons Attribution License, which permits unrestricted use, distribution, and reproduction in any medium, provided the original work is properly cited.

\begin{abstract}
Objective: We hypothesized that preeclamptic women with intrauterine growth restriction (IUGR) would have lower concentrations of leptin compared to women with normal fetal growth. Methods: A crosssectional study was performed in 20 cases of IUGR and 20 normal fetuses born to women diagnosed with preeclampsia. Blood samples were collected from mothers at term gestation and with fetal birth weight less than 2500 grams would categorized as IUGR. The subjects were recruited by consecutive sampling conducted in Hasan Sadikin Hospital and several network hospitals during the period of September-November 2012. Results: A significant difference $(p=$ $0.015)$ in maternal serum leptin levels was found between IUGR $(22.1 \mathrm{ng} / \mathrm{ml})$ and normal fetuses $(36.5$ $\mathrm{ng} / \mathrm{ml})$. Serum levels of leptin in preeclamptic women with IUGR were lower than normal fetuses. Spearman correlation test between maternal serum leptin levels and birth weight in IUGR did not demonstrate a significant correlation, with $r=-0.321(p=0.168)$. Conclusion: The maternal leptin concentrations in IUGR are lower than the normal fetus in preeclampsia cases, but there was not enough evidence to support that leptin is associated with birth weight in IUGR.
\end{abstract}

Keywords: Leptin; Intrauterine Growth Restriction; Small for Gestational Age; Preeclampsia

\section{INTRODUCTION}

Intrauterine growth restriction (IUGR) is associated with perinatal mortality and morbidity. The most widely used definition of IUGR is a fetus whose estimated weight is

\footnotetext{
*All the authors declare that they have no conflicts of interest.

${ }^{\#}$ Corresponding author.
}

below the 10th percentile for its gestational age. At term, the cutoff birth weight for IUGR is $2500 \mathrm{~g}$ [1]. The prevalence of IUGR in the world is 6 times higher in developing countries, $75 \%$ of which are located in Asia [2]. In Indonesia, the average prevalence from 4 centers of Maternal-Fetal Medicine during the period from 2004 to 2005 was $4.4 \%$, with the highest prevalence $(6.44 \%)$ reported in Sardjito Yogyakarta Hospital [3]

Leptin is a 167-amino acid protein, the product of the obese (ob) gene, mainly produced by fat cells [4]. Leptin is a peptide hormone regulating the energy homeostasis, reproductive function and immunologic reaction, and produced in the adipose tissue of non-pregnant women. During pregnancy, it is produced primarily by placental trophoblast cells and $95 \%$ is present in the maternal circulation $[5,6]$.

Leptin concentration increases significantly in early pregnancy and reached $30 \%$ higher at 12 weeks of gestation compared with pregravid [6]. The relationship between maternal leptin levels and the fetal growth is not yet determined; whereas, fetal leptin concentrations represent the fetal adiposity. Abnormal increases in serum leptin production by the placenta during pregnancy illustrate the response to hypoxia due to ischemia placental trophoblast as observed in preeclampsia [6,7].

This situation is similar to that occurring in IUGR, where increased leptin is suggested to promote the mobilization fat reserves to improve the availability and support the transplacental transfer of lipid substrate and angiogenesis; leptin has the ability to enhance the transport of amino acids in the placenta $[8,9]$. Increased availability of nutrients is consistent with the observation that despite the decrease in placental perfusion, only one-third of neonates born from preeclamptic women have IUGR. In other words, preeclampsia is associated with the signal of fetus-placenta to increase the availability of nutrients and leptin production is the appropriate solution [10]. Recent studies regard- 
ing maternal leptin levels and fetal weight showed inconsistent results; leptin is associated with maternal morbidities, body mass index (BMI), smoking habits, as well as other complications [11-13]. This study aimed to determine the role of leptin in the growth of fetuses in mothers with preeclampsia. We evaluated maternal serum leptin in two groups: preeclampsia with and without IUGR.

\section{SUBJECTS AND METHOD}

The study is an observational analytic study with cross sectional method to compare the differences of maternal serum leptin levels in fetuses with normal growth and IUGR in preeclampsia, as well as to measure the magnitude of correlation of maternal serum leptin levels with fetal birth weight in preeclampsia. The study was conducted at the Department of Obstetrics and Gynecology RSHS Bandung and several network hospitals in West Java (Ujung Berung Hospital, Soreang Hospital, Astana Anyar Hospital, and Cibabat Hospital) between September-November 2012. It has received ethical approval from the Faculty of Medicine, University of Padjadjaran Bandung.

Subjects are pregnant women with single live fetus, who was diagnosed with preeclampsia (systolic blood pressure $>140 \mathrm{mmHg}$ or diastolic blood pressure $>90$ $\mathrm{mmHg}$ and the urine protein + or more), gestational age limit 37 - $42 \mathrm{wks}$, had a normal BMI before pregnancy, did not have any co-morbidities such as heart failure, pulmonary tuberculosis, systemic lupus erythematous and diabetes mellitus, had no history of smoking before or during pregnancy and there were no birth defects in the fetus. Clinical characteristics of participating pregnant women are presented in Table 1.

Maternal blood samples (approximately $5 \mathrm{cc}$ ) were taken during labor, inserted into a sterile tube, centrifuged at $3000 \mathrm{rpm}$ for $15 \mathrm{~min}$, and then frozen at $-20 \mathrm{Co}$. Leptin measurement was performed using Elisa reagent kit from R \& D system. Intra-assay and inter-assay precisions for leptin measurement are $3.8 \%$ and $5 \%$, respectively. All infants born were recorded; infants born at less than 2500 grams were assigned into IUGR group and those at more than 2500 grams were allocated into normal fetuses group, resulting in 20 samples for each group. Maternal data including parity, age, systolic and diastolic blood pressure, proteinuria and maternal BMI before pregnancy was obtained from patient records antenatal visit and BMI at the time.

Statistical analysis: the data was analyzed using SPSS for Windows version 18.0. This study used a nonparametric method after the data obtained did not show a normal distribution. Analysis of the differences was performed using the Mann-Whitney test and correlation for further assessment using the Spearman rank test.
Table 1. Characteristics of pregnant women with IUGR and normal fetus.

\begin{tabular}{llll}
\hline Characteristics & IUGR & Normal fetus & $p$ value \\
1) Age & & & \\
$<20$ & 2 & 4 & 0.255 \\
$20-29$ & 6 & 3 & \\
$30-39$ & 10 & 13 & \\
$40+$ & 2 & - & \\
Mean & $30.55( \pm 6.84)$ & $28.90( \pm 6.85)$ & 0.451 \\
Range & $16-41$ & $15-38$ & \\
$2)$ Parity & & & \\
0 & 6 & 10 & 0.389 \\
$1-3$ & 11 & 7 & \\
$4+$ & 3 & 3 &
\end{tabular}

3) Mean Body Mass Index (BMI)

$\begin{array}{llll}\text { Before Pregnancy } & 22.03( \pm 2.4) & 22.80( \pm 2.71) & 0.351 \\ \text { During Pregnancy } & 27.03( \pm 3.08) & 28.20( \pm 3.44) & 0.266\end{array}$

4) Blood Pressure

Systolic $(\mathrm{mmHg}) \quad 172.0( \pm 17.6) \quad 110( \pm 12.9) \quad 0.128$

Diastolic (mmHg) $\quad 110( \pm 12.9) \quad 103.5( \pm 7.45) \quad 0.061$ $\begin{array}{lll}\text { 5) Mean Birth Weight } & 2085( \pm 300.9) & 3047( \pm 367.13) \\ \text { Interval } & 1650-2450 & 2500-3900\end{array}$

${ }^{*}$ Significant $(\mathrm{p}<0.05)$.

\section{RESULT}

There was no statistically significant differences in the characteristics between the subjects in IUGR and normal fetal growth groups ( $n=20$ in each group) who met the inclusion criteria in Hasan Sadikin Hospital and network hospitals, including for maternal age $(\mathrm{p}=$ $0.255)$, parity $(0.389)$ and BMI before pregnancy $(\mathrm{p}=$ $0.351)$ and during pregnancy $(\mathrm{p}=0.266)$.

Table 1 shows the comparison of characteristics of infant birth weight between the IUGR fetuses and normal fetuses. The average birth weight for the infants with IUGR and normal fetuses were 2085 (SD \pm 300.9$)$ and 3047 ( $\mathrm{SD} \pm 367.13)$, respectively. We did find that systolic and diastolic blood pressure in IUGR group was not significantly different with normal fetus group. Table 2 shows that the average leptin level of IUGR group $(22.9 \pm 16.8 \mathrm{ng} / \mathrm{ml})$ was lower than normal fetuses group $(36.21 \pm 17.0 \mathrm{ng} / \mathrm{ml})$. The median leptin level of IUGR and normal fetuses were $16.09 \mathrm{ng} / \mathrm{ml}$ and $34.43 \mathrm{ng} / \mathrm{ml}$, respectively. The Mann-Whitney test showed a statistically significant difference $(p=0.015)$ between the leptin concentrations in IUGR and normal fetuses. Table 3 shows the results of the statistical test 
Table 2. The maternal serum leptin levels normal fetus and IUGR.

\begin{tabular}{|c|c|c|c|}
\hline \multirow[b]{2}{*}{$\begin{array}{l}\text { Leptin Levels } \\
(\mathrm{Ng} / \mathrm{ml})\end{array}$} & \multicolumn{2}{|c|}{ Group } & \multirow[b]{2}{*}{$\mathrm{p}$ value } \\
\hline & $\begin{array}{c}\text { IUGR } \\
(\mathrm{N}=20)\end{array}$ & $\begin{array}{l}\text { Normal } \\
(\mathrm{N}=20)\end{array}$ & \\
\hline $\begin{array}{c}\text { Mean }( \pm \mathrm{SD}) \\
\text { Interval }\end{array}$ & $\begin{array}{c}22.9(16.8) \\
3.37 \text { to } 67.08\end{array}$ & $\begin{array}{l}36.21(17.0) \\
9.7 \text { to } 77.05\end{array}$ & $0.015^{*}$ \\
\hline
\end{tabular}

*Significant $(\mathrm{p}<0.05)$.

Table 3. Correlation between leptin levels and birth weight infants.

\begin{tabular}{ccc}
\hline Correlation of variables & $r$ & p value \\
\hline Leptin Levels with Birth Weight Infants & -0.321 & 0.168 \\
\hline
\end{tabular}

with Spearman correlation test at the $95 \%$ confidence level indicates that there is no significant correlation between leptin levels with birth weight infant $(r=$ $-0.321 ; \mathrm{p}=0.168$ ).

\section{DISCUSSION}

The result of this study showed that leptin levels in normal growth fetuses at term gestational age was 36.21 $(\mathrm{SD} \pm 17.0)$ with a mean fetal weight of 3047 grams. These results are consistent with previous researches that showed that the levels of leptin in maternal preeclampsia was $35.8(\mathrm{SD} \pm 22.0)$ with mean birth weight of 3150 grams [14]. Other previous studies showed various results of maternal plasma leptin levels in preeclamptic pregnancy at term, with the mean of 45.6 (32.4 to 60.4) $\mathrm{ng} / \mathrm{mL}[6] ; 47.8 \pm 6.9 \mathrm{ng} / \mathrm{mL}$ [15], and 27.13 (14.4 to 49.5) $\mathrm{ng} / \mathrm{mL}[16]$.

The values of leptin levels found in our study [22.9 $(\mathrm{SD} \pm 6.8)]$ is lower than in a previous research. They found a higher mean maternal leptin levels in preeclampsia with IUGR at $26.5(\mathrm{SD} \pm 3.8) \mathrm{ng} / \mathrm{mL}$, with the average BMI of $30.3 \mathrm{~kg} / \mathrm{m}^{2}$ (obese category) during the third trimester, which is a higher BMI compared the index in our study, $27.3 \mathrm{~kg} / \mathrm{m}^{2}$ (during pregnancy) and $22.03 \mathrm{~kg} / \mathrm{m}^{2}$ (pre-pregnancy) [17].

The pre-pregnancy BMI has an effect on maternal leptin levels and its effect seems to be weaker during pregnancy. In the non-pregnant state, the level of leptin produced by adipose tissue is directly related to BMI and the leptin level is increased in women with insulin resistance. Leptin clinically represents the adipose reserves in the human body [18-20]. Levels of leptin in pregnancy are lower on women with normal BMI than on women with overweight or obese [21]. In the current study, the influence of BMI on leptin level had reduced, because BMI between sample was similar.
A prospective study showed that lower leptin levels in the early trimester poses a higher risk of fetal weight growth failure and having a smaller fetus [22]. Another research reported that mothers of small for gestational age (SGA) infants had lower leptin level than the mothers of infants with appropriate weight-for-gestational age infants [10,11]. Lower leptin levels in IUGR suggests the possibility of leptin expression failure in the placenta as the response to hypoxia that should spur the production of leptin to improve the lack of uteroplacental perfusion. Placental leptin expression and growth factors level were lower in small for gestational age infant compared to normal infants [10]. We speculate that low leptin levels would lead to the impairment of the compensation mechanism to increase nutrients transfer in the placenta which would result in restricted fetal growth. The effects of leptin on growth and development in the fetus, may be cell- and tissue-specific rather than on general body growth and size [9].

Conflicting results have been reported from leptin studies that compare pregnancies with IUGR and pregnancies with normal fetal growth. Some studies showed no significant differences in leptin levels between the two groups $[15,23,24]$. Several studies reported that mothers of a SGA infants had higher leptin levels compared mothers of normal birth weight infants $[12,17,25,26]$. It may be explained by the notion that leptin levels were higher in mothers with preeclamptic SGA infants compared to normal infants, due to the occurrence of chronic hypoxia that causes the disorder to affect the nutrition and eventually results in IUGR. Placental hypoperfusion causes local hypoxia, which triggers increased production of leptin by the placenta $[25,26]$. However, worsening of placental function sometimes advances rapidly in preeclamptic women accompanied with elevated blood pressure. In that condition, increased placental leptin production may take place, while fetal growth restriction may not become apparent in a short duration. Otherwise in women with slowly progressing disease, maternal plasma leptin levels may not increase so highly in spite of more apparent restriction in fetal growth [25].

Relations between leptin levels and birth weight were reported in Nezar's studies, which suggested that leptin level is negatively correlated with fetal weight [17]. However, in our study found no significant correlation between maternal leptin levels and birth weight as shown in Table 3. Factors that influence these results include differences in the number and characteristics of the sample, the sample selection criteria in full-term pregnancies; different BMI. The limitation in our study was ability to confirm that the restricted growth by serial ultrasound diagnosis was not available.

Based on the results of this study we concluded that the levels of leptin of preeclamptic women with IUGR 
fetuses is lower than those with normal fetuses; thus, it can be used as a complement to indicate fetal growth, although a direct correlation between leptin and fetal growth still has not been proven unequivocally. Further research, especially serial examinations of leptin with serial biophysical fetal during pregnancy, would be a substantial additional information in the pathogenesis of fetal growth.

\section{REFERENCES}

[1] Peleg, D., Kennedy, C.M. and Hunter, K.S. (1998) Intrauterine growth restriction: Identification and management. American Family Physician, 58, 453-460.

[2] de Onis, M., Blossner, M. and Villar, J. (1998) Levels and patterns of intrauterine growth retardation in developing countries. European Journal of Clinical Nutrition, 52, S5-S15.

[3] Indonesian Society of Maternal Fetal Medicine (2010) Management of intrauterine growth restriction. Guideline for the management of obstetric cases. 1st Edition, Indonesian Society of Maternal Fetal Medicine.

[4] Ahima, R.S. and Flier, J.S. (2000) Leptin. Annual Review of Physiology, 62, 413-437. doi:10.1146/annurev.physiol.62.1.413

[5] Yura, S., Itoh, H., Sagawa, N., et al. (2005) Role of premature leptin surge in obesity resulting from intrauterine undernutrition. Cell Metabolism, 1, 371-378. doi:10.1016/j.cmet.2005.05.005

[6] Hauguel-de Mouzon, S., Lepercq, J. and Catalano, P. (2006) The known and unknown of leptin in pregnancy. American Journal of Obstetrics \& Gynecology, 194, 1537-1545. doi:10.1016/j.ajog.2005.06.064

[7] McCarthy, J.F., Misra, D.N. and Roberts, J.M. (1999) Maternal plasma leptin is increased in preeclampsia and positively correlates with fetal cord concentration. American Journal of Obstetrics \& Gynecology, 180, 731-736. doi:10.1016/S0002-9378(99)70280-2

[8] Henson, M.C. and Castracane, V.D. (2006) Leptin in pregnancy: An update. Biology of Reproduction, 7, 218229. doi:10.1095/biolreprod.105.045120

[9] Forhead, A.J. and Fowden, A.L. (2009) The hungry fetus? Role of leptin as a nutritional signal before birth. The Journal of Physiology, 587, 145-152. doi:10.1113/jphysiol.2008.167072

[10] Catov, J.M., Patrick, T.E., Powers, R.W., et al. (2007) Maternal leptin across pregnancy in women with smallfor-gestational-age infants. American Journal of Obstetrics \& Gynecology, 196, 558.e1-558.e8. doi:10.1016/j.ajog.2007.01.032

[11] Yildiz, L., Avci, B. and Ingec, M. (2002) Umbilical cord and maternal blood leptin concentrations in intrauterine growth retardation. Clinical Chemistry and Laboratory Medicine, 40, 1114-1117. doi:10.1515/cclm.2002.195

[12] Pighetti, M., Tommaselli, G.A., D'Elia, A., et al. (2003) Maternal serum and umbilical cord blood leptin concentrations with fetal growth restriction. Obstetrics \& Gyne- cology, 102, 535-543. doi:10.1016/S0029-7844(03)00668-9

[13] Tamura, T., Goldenberg, R.L., Johnston, K.E. and Cliver, S.P. (1998) Serum leptin concentrations during pregnancy and their relationship to fetal growth. Obstetrics \& Gynecology, 91, 389-395. doi:10.1016/S0029-7844(97)00670-4

[14] Resistantie, N. (2004) Perbandingan kadar leptin serum penderita preeklamsi dan kehamilan normal serta hubungannya dengan berat bayi lahir. Tesis, Universitas Padjadjaran, Bandung.

[15] Laivuori, H., Gallaher, M.J., Collura, L., et al. (2006) Relationships between maternal plasma leptin, placental leptin mRNA and protein in normal pregnancy, preeclampsia and intrauterine growth restriction without preeclampsia. Molecular Human Reproduction, 12, 551-556. doi:10.1093/molehr/gal064

[16] Anim-Nyame, N., Sooranna, S.R., Steer, P.J. and Johnson, M.R. (2000) Longitudinal analysis of maternal plasma leptin concentrations during normal pregnancy and preeclampsia. Human Reproduction, 15, 2033-2036. doi:10.1093/humrep/15.9.2033

[17] Nezar, M.A., El-Baky, A.M., Soliman, O.A., et al. (2009) Endothelin-1 and leptin as markers of intrauterine growth restriction. The Indian Journal of Pediatrics, 76, 485-488. doi:10.1007/s12098-009-0079-0

[18] Considine, R.V., Sinha, M.K., Heiman, M.L., et al. (1996) Serum Immunoreactive-leptin concetration in normal weight and obese human. The New England Journal of Medicine, 334, 292-295. doi:10.1056/NEJM199602013340503

[19] Mantziros, C.S. (1999) The role of leptin in human obesity and disease: A review of current evidence. Annals of Internal Medicine, 130, 671-680. doi:10.7326/0003-4819-130-8-199904200-00014

[20] Aizawa, A.M., Ogawa, Y., Masuaki, H., et al. (2000) Pathophysiological role of leptin in obesity related hypertension. The Journal of Clinical Investigation, 105, 1234-1252. doi:10.1172/JCI8341

[21] Hendler, I., Blackwell, S.C., Mehta, S.H., et al. (2005) The levels of leptin, adiponectin, and resistin in normal weight, overweight, and obese pregnant women with and without preeclampsia. American Journal of Obstetrics \& Gynecology, 193, 979-983. doi:10.1016/j.ajog.2005.06.041

[22] Franco-Sena, A.B., Goldani, M.Z., Tavares do Carmo, M.G., Velásquez-Melendez, G. and Kac, G. (2010) Low leptin concentration in the first gestational trimester is associated with being born small for gestational age: Prospective study in Rio de Janeiro, Brazil. Neonatology, 97, 291-298. doi:10.1159/000255160

[23] Grisaru-Granovsky, S., Eitan, R., Algur, N., et al. (2003) Maternal and umbilical cord serum leptin concentrations in small-for-gestational-age and in appropriate for gestational age neonates: A maternal, fetal, or placental contribution? Biology of the Neonate, 84, 67-72. doi:10.1159/000071447

[24] Varvarigou, A., Mantzoros, C.S. and Beratis, N.G. (1999) 
Cord blood leptin concentrations in relation to intrauterine growth. Clinical Endocrinology, 50, 177-183.

doi:10.1046/j.1365-2265.1999.00630.x

[25] Mise, H., Yura, S., Itoh, H., Nuamah, M.A., et al. (2007) The relationship between maternal plasma leptin levels and fetal growth restriction. Endocrine Journal, 54, 945-
951. doi:10.1507/endocrj.K06-225

[26] Nakatsukasa, H., Masuyama, H., Takamoto, N. and Hiramatsu, Y. (2008) Circulating leptin and angiogenic factors in preeclampsia patients. Endocrine Journal, 55, 565-573. doi:10.1507/endocrj.K07E-136 